Article

\title{
Impact of Genotype, Weather Conditions and Production Technology on the Quantitative Profile of Anti-Nutritive Compounds in Rye Grains
}

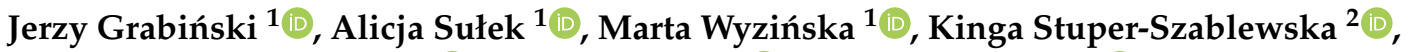 \\ Grażyna Cacak-Pietrzak ${ }^{3, *(D)}$, Anna Nieróbca ${ }^{4}$ (D) and Dariusz Dziki ${ }^{5}$ (D) \\ 1 Department of Cereal Crop Production, Institute of Soil Science and Plant Cultivation-State Research \\ Institute, 8 Czartoryskich Street, 24-100 Pulawy, Poland; jurek@iung.pulawy.pl (J.G.); \\ sulek@iung.pulawy.pl (A.S.); mwyzinska@iung.pulawy.pl (M.W.) \\ 2 Department of Chemistry, University of Life Sciences, 75 Wojska Polskiego Street, 60-625 Poznan, Poland; \\ kinga.stuper@up.poznan.pl \\ 3 Division of Fruits, Vegetables and Cereals Technology, Warsaw University of Life Science, \\ 159C Nowoursy-nowska Street, 02-786 Warsaw, Poland \\ 4 Department of Agrometeorology and Applied Informatics, Institute of Soil Science and Plant \\ Cultivation-State Research Institute, 8 Czartoryskich Street, 24-100 Pulawy, Poland; \\ a.nierobca@iung.pulawy.pl \\ 5 Department of Thermal Technology and Food Process Engineering, University of Life Sciences in Lublin, \\ 31 Głęboka Street, 20-612 Lublin, Poland; dariusz.dziki@up.lublin.pl \\ * Correspondence: grazyna_cacak_pietrzak@sggw.edu.pl; Tel.: +48-22-5937541
}

\section{check for}

updates

Citation: Grabiński, J.; Sułek, A.; Wyzińska, M.; Stuper-Szablewska, K.; Cacak-Pietrzak, G.; Nieróbca, A.; Dziki, D. Impact of Genotype, Weather Conditions and Production Technology on the Quantitative Profile of Anti-Nutritive Compounds in Rye Grains. Agronomy 2021, 11, 151. https://doi.org/10.3390/ agronomy11010151

Received: 30 November 2020 Accepted: 11 January 2021 Published: 14 January 2021

Publisher's Note: MDPI stays neutral with regard to jurisdictional clai$\mathrm{ms}$ in published maps and institutional affiliations.

Copyright: $(\odot 2021$ by the authors. Licensee MDPI, Basel, Switzerland. This article is an open access article distributed under the terms and conditions of the Creative Commons Attribution (CC BY) license (https:// creativecommons.org/licenses/by/ $4.0 /)$.

\begin{abstract}
The main anti-nutritive substances present in rye grains include alkylresorcinols, watersoluble pentosans, and trypsin inhibitors. The content of these compounds in the grains can be influenced by genetic factors, habitat conditions and the crop management technology used in cultivation. The aim of the study was to determine the variability of the concentration of anti-nutritive compounds in rye grains depending on the variety, weather conditions and production technology. The field research was conducted at the IUNG-PIB Experimental Station in Osiny (Poland) in three growing seasons 2010/2011, 2011/2012 and 2012/2013. The experiment was located on lessive soil, on plots of $45 \mathrm{~m}^{2}$ in three replications. The first factor was the type of production technology (integrated and intensive), while the second was a variety of winter rye. Two hybrid varieties (Brasetto, Visello) and two population varieties (Dańkowskie Diament, Kier) were included. The research showed that the content of anti-nutritive compounds in rye grains depended significantly on the genotype and weather conditions. Stress conditions during the rye growing season in 2011 and 2013 were the cause of higher synthesis of alkylresorcinols, soluble pentosans and trypsin inhibitors in rye grains. The content of alkylresorcinols and water-soluble pentosans also depended significantly on the intensity of the production technology. The higher content of these compounds was found in rye grains from intensive technology. The production technology had no significant impact on the activity of trypsin inhibitors.
\end{abstract}

Keywords: rye; production technology; varieties; alkylresorcinols; water-soluble pentosans; trypsin inhibitors

\section{Introduction}

Rye (Secale cereale L.) is a cereal plant commonly grown in northern, central and eastern Europe [1]. In the season 2017/2018 the worldwide rye harvest was 11,274 million tons. Internationally, the leading rye producers are Germany (19.9\% of world production), Poland (19.5\%), Russia (18.5\%) and Denmark (5.3\%) [2].

The yield and quality of the rye is influenced by genetic factors and the cultivation conditions used. Particular varieties of rye differ in terms of agricultural characteristics 
(yielding, resistance to lodging, diseases and pests), as well as the chemical composition and end-use value of the grain. The most commonly cultivated are the population cultivars of rye. They are cultivated and propagated in a traditional way (all stages of reproduction are identical) [3]. In recent years, hybrid varieties of rye have been gaining popularity. Compared to population varieties, these varieties are characterized by a $20-30 \%$ higher yield and higher resistance to diseases and lodging, high adaptability, resistance to soil quality, and stressful environmental conditions [4].

Rye, compared to other cereal crops, has lower soil and climate requirements. It can be grown in poorer soils, and is resistant to low temperatures (up to $-25^{\circ} \mathrm{C}$ ). Thanks to the strongly developed root system and economical water management, it is also resistant to drought and water deficit [5]. Rye can be grown using various production technologies. The most commonly used are intensive and integrated technology. The intensive technology is characterized by a wide use of industrial means of production, mineral fertilizers (mainly NPK) and chemical plant protection products, which ensures high yields, but is associated with many threats to the natural environment. In integrated technology, the means of production are used in moderate amounts, e.g., nitrogen fertilization is $30-40 \%$ lower compared to intensive technology, and protection treatments are performed depending on the intensity of pests [6].

The basic direction of using rye grains is milling them into flours, used as a raw material for the production of various assortments of rye and mixed bakery products, and also as an addition to wheat flour in the production of certain pastry products (e.g., gingerbread and crackers) [5,7-9]. According to the data of the Association of Polish Mills [10], 850-900 thousand tons of rye grains (about $40 \%$ of the harvest) are allocated annually for milling purposes in Poland, from which about 700 thousand tons of flour is obtained. Rye grains are also a raw material for the production of flakes, malt and ethanol [5]. In addition to their consumption and industrial purposes, rye grains are widely used in animal nutrition [5,11].

Rye grains are a source of saccharides, protein, fat, minerals, and B vitamins $[3,5,7]$. Compared to other cereals, rye has the highest content of bioactive substances, therefore the consumption of rye products has a positive effect on the human body. The bioactive substances of rye include vitamin E, provitamin A and dietary fiber, with its main components such as arabinoxylates, oligosaccharides and lignin, followed by phytates and the whole range of phenolic compounds left over from lignin, including phenolic acids and alkylresorcinols $[7,12,13]$.

The bioactive ingredients in the cereal grain contain anti-nutritional compounds, the presence of which reduces the nutritional and fodder value of this grain. This group includes alkylresorcinols, non-starch polysaccharides, protease inhibitors, tannins and lectins [12,13]. Anti-nutritional substances, referred to as antimethabolites, reduce the digestibility and absorption of nutrients, thus reducing the amount of nutrients absorbed by the body [11]. Anti-nutritional compounds are mainly located in the outer parts of the grains, and during milling into flours, they are transferred to a by-product (bran), therefore, their presence in food products is much lower than in the grains used for animal feeding $[5,7,11]$.

Alkylresorcinols, derivatives of phenols, are found only in the outer layers of grains [14,15]. According to the literature [15-18] they are located in the outer layer of the fruit and seed coat in the cuticle. Rye, next to triticale, is the richest cereal in terms of the content of alkylresorcinols. Their content in rye grains may even reach $1800 \mathrm{mg} \cdot \mathrm{kg}^{-1} \mathrm{~d} . \mathrm{m}$., while in wheat grains their amount does not exceed $700 \mathrm{mg} \cdot \mathrm{kg}^{-1} \mathrm{~d} . \mathrm{m}$. , and in barley grains $200 \mathrm{mg} \cdot \mathrm{kg}^{-1} \mathrm{~d}$.m [19]. They have a protective function in grains, and are considered to have bacterio- and fungicidal effects [20]. Because the compounds are of phenolic structure, they show strong antioxidant properties $[13,21]$. The negative nutritional effect of these compounds is the deterioration of protein digestibility. The results of production studies indicate that, compared to other anti-nutritive substances present in cereal grain, the negative effect of alkylresorcinols is relatively small [22]. The literature indicates that the 
content of alkylresorcinols in cereal grains is a feature mainly dependent on the genetic factor $[13,23]$, but may be to some extent shaped by soil-climatic conditions and cultivation technology [24,25].

Saccharides are one of the basic groups of chemical compounds contained in rye grain. In addition to the basic saccharide starch, rye contains water-soluble sugars and non-starch polysaccharides, including pentosans (arabinoxylates), uronic acids (pectin) and $\beta$-glucans. The content of starch and pentosan as well as the activity of enzymes hydrolysing these compounds, determine the specific technological properties of rye $[8,9,26]$. Pentosans, whose content in rye grain reaches $8 \%$, are able to absorb up to $800 \%$ of water compared to their weight, which contributes to the protection of starch against enzymatic decomposition [27]. Pentosans, especially water-soluble ones, due to their high water absorption and high viscosity in the aqueous environment, result in worse utilization of the nutrients contained in the feed. They form permanent complexes with proteins that become less accessible to proteolytic enzymes in the gastrointestinal tract, which results in poorer digestibility of both proteins and pentosans themselves. Rye pentosans are only digested in the small intestine at a rate of about $5 \%$. Undigested protein-pentosan complexes may cause excessive development of intestinal microflora, which in combination with swelling pentosans, reduces the absorption of calcium and vitamin $\mathrm{D}$. They also have the ability to bind to bile acids, thus worsening digestion and use of fats from feed [28].

Protease inhibitors (trypsin and chymotrypsin) are mainly synthesized in plant tissues [29]. They are likely part of the plant defense system, inhibiting numerous digestive enzymes of herbivorous animals [30]. The mechanism of action of the inhibitors is to create inactive complexes with digestive enzymes. The negative effect of the inhibitors comes down to blocking trypsin, which results in the inhibition of some processes involving this enzyme, causing lower protein proteolysis in the gastrointestinal tract, which results in limiting their use [14,31]. This results in the inhibition of animal growth [32]. These compounds are particularly dangerous for monogastric animals, which may cause hyperplastic pancreatic changes as a result of long-term administration. The total activity of trypsin rye inhibitors is mainly accumulated in the endosperm. Their activity is related to low molecular weight proteins (albumin, globulin). The activity of trypsin inhibitors in rye grains depends mainly on the genotype $[13,15]$. It is also shaped by climatic and soil conditions and storage time of the grains after harvest $[33,34]$.

The aim of this study was to determine the variability of the concentration of antinutritive compounds in rye grains depending on the variety, weather conditions and production technology.

\section{Materials and Methods}

\subsection{Site Characteristic, Experimental Design, and Agronomic Paractices}

The field experiment was conducted in the growing seasons 2010/2011, 2011/2012 and $2012 / 2013$ at the Experimental Station IUNG-PIB in Osiny $\left(51^{\circ} 27^{\prime} \mathrm{N} ; 22^{\circ} 2^{\prime}\right.$ E), Poland. The experiment was located on lessive soil (Luvisol), on plots sizes of $45 \mathrm{~m}^{2}$, and the conditions were was established using the random subblocks method in 3 replications. Cereals were used as the forecrop. The first factor (A) was the variety. We tested the varieties Brasetto F1, Visello F1 (hybrid varieties), and Dańkowskie Diament, Kier (population varieties). The second factor was the type of technology, namely integrated or intensive (B), which was diversified in terms of the doses of mineral fertilizers and the intensity of plant chemical protection. The specification of treatments is given in Table 1. 
Table 1. Characterization of applied technologies for rye winter production.

\begin{tabular}{|c|c|c|}
\hline \multirow{2}{*}{ Specification } & \multicolumn{2}{|c|}{ Production Technology } \\
\hline & Integrated & Intensive \\
\hline $\begin{array}{c}\text { Fertilization } \\
\left(\mathrm{kg} \cdot \mathrm{h}^{-1}\right)\end{array}$ & 50 (start of vegetation) & $\begin{array}{c}50 \text { (start of vegetation) } \\
20 \text { (at BBCH 51) }\end{array}$ \\
\hline $\mathrm{N}$ (ammonium nitrate) & 30 (at BBCH 51) & 50 (at BBCH 31) \\
\hline P (superphosphate) & 60 & 60 \\
\hline K(potassium salt) & 90 & 90 \\
\hline $\begin{array}{l}\text { Herbicide } \\
\left(\mathrm{g} \cdot \mathrm{ha}^{-1}\right)\end{array}$ & \multicolumn{2}{|c|}{ At $\mathrm{BBCH} 20$ difufenican $-50+$ chlorotoluron -1000} \\
\hline $\begin{array}{l}\text { Fungicide } \\
\left(\mathrm{L} \cdot \mathrm{h}^{-1}\right)\end{array}$ & $\begin{array}{c}\text { At BBCH } 39 \text { epoxiconazole }-0.7+ \\
\text { tebuconazole }-0.4\end{array}$ & $\begin{array}{l}\text { At BBCH } 31 \text { tebuconazole } 0.4+ \\
\text { prochloraz } 0.5+\text { phenopropidine }-0.3) \text {, } \\
\text { and BBCH } 51 \text { epoxiconazole }-0.8\end{array}$ \\
\hline
\end{tabular}

\subsection{Meteorological Conditions}

The data on weather conditions came from the IUNG-PIB Meteorological Station located on the premises of the Experimental Station in Osiny, where field research was conducted. Weather conditions were assessed on the basis of the average monthly values of air temperature and total precipitation, and then compared with the averages from the 1981-2010 period. The years in which the field studies were conducted differed in terms of the course of thermal conditions and the distribution of precipitation during the growing season. The $2010 / 2011$ season was characterized by the highest temperature variability (Figure 1). After the cold September and October, when temperatures were by $1.2{ }^{\circ} \mathrm{C}$ and $3.0^{\circ} \mathrm{C}$ lower than the long-term means, there was a period of noticeable warming in November (average temperature of $6.5^{\circ} \mathrm{C}$ and $3.3^{\circ} \mathrm{C}$ higher than the long-term means), and then there was a cooling in December, where the average monthly temperature was $-4.6^{\circ} \mathrm{C}$, which was by $3.8^{\circ} \mathrm{C}$ lower than the long-term means. January was warmer, but another cooling occurred in February with the average temperature of $-3.7^{\circ} \mathrm{C}$, which is $-2.5^{\circ} \mathrm{C}$ lower than the long-term mean. From March to the end of the growing season, the air temperatures were higher or close to the long-term mean.

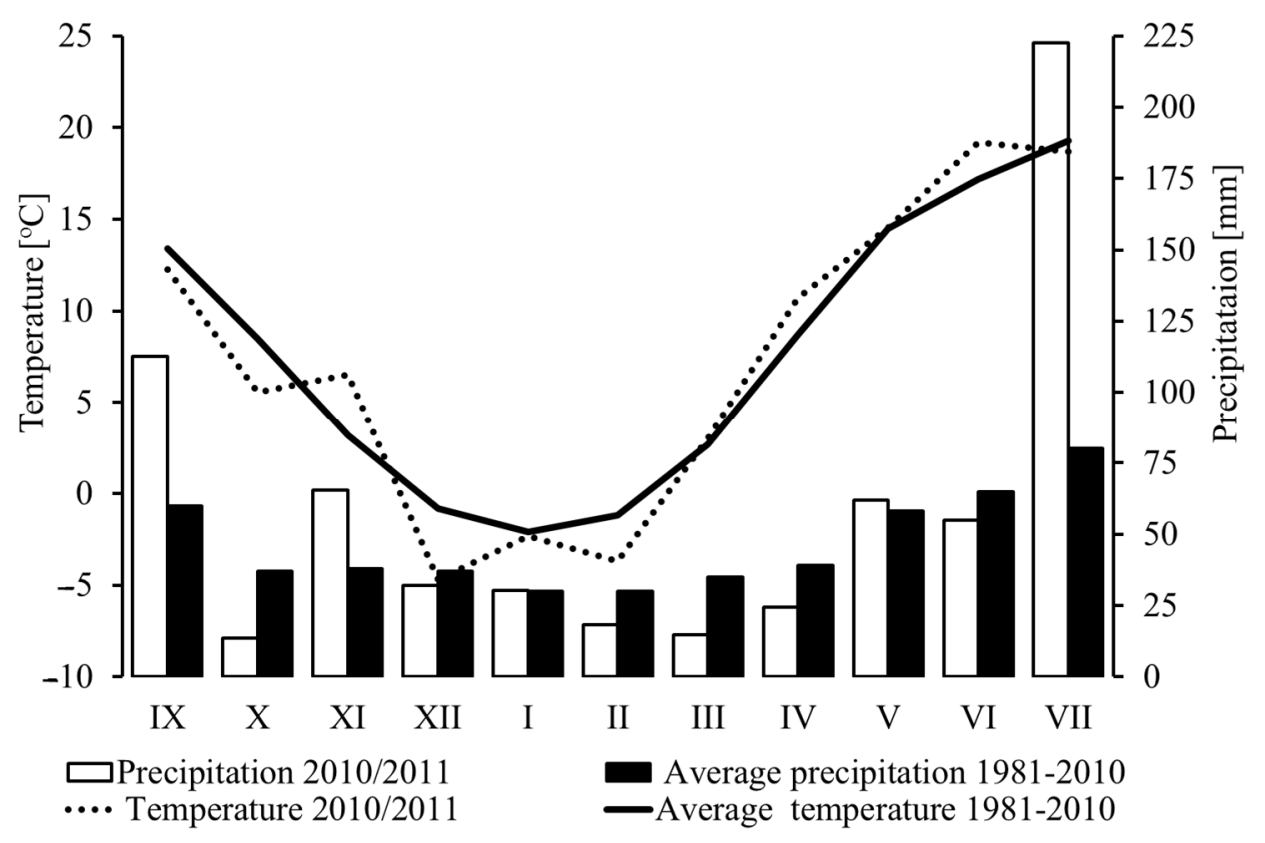

Figure 1. Monthly mean air temperature $\left({ }^{\circ} \mathrm{C}\right)$ and monthly sum of precipitation (mm) in years 2010/2011. 
The 2011/2012 growing season was characterized by a very warm December (average temperature of $2.5^{\circ} \mathrm{C}$ ), which was by $3.3^{\circ} \mathrm{C}$ warmer than the long-term mean, and a very cold February (average temperature $-6.3{ }^{\circ} \mathrm{C}$ ) (Figure 2). The occurrence of low temperatures in the absence of snow cover contributed to the partial freezing of crops. Later in the growing season, the air temperatures were higher than the average temperatures from many years.

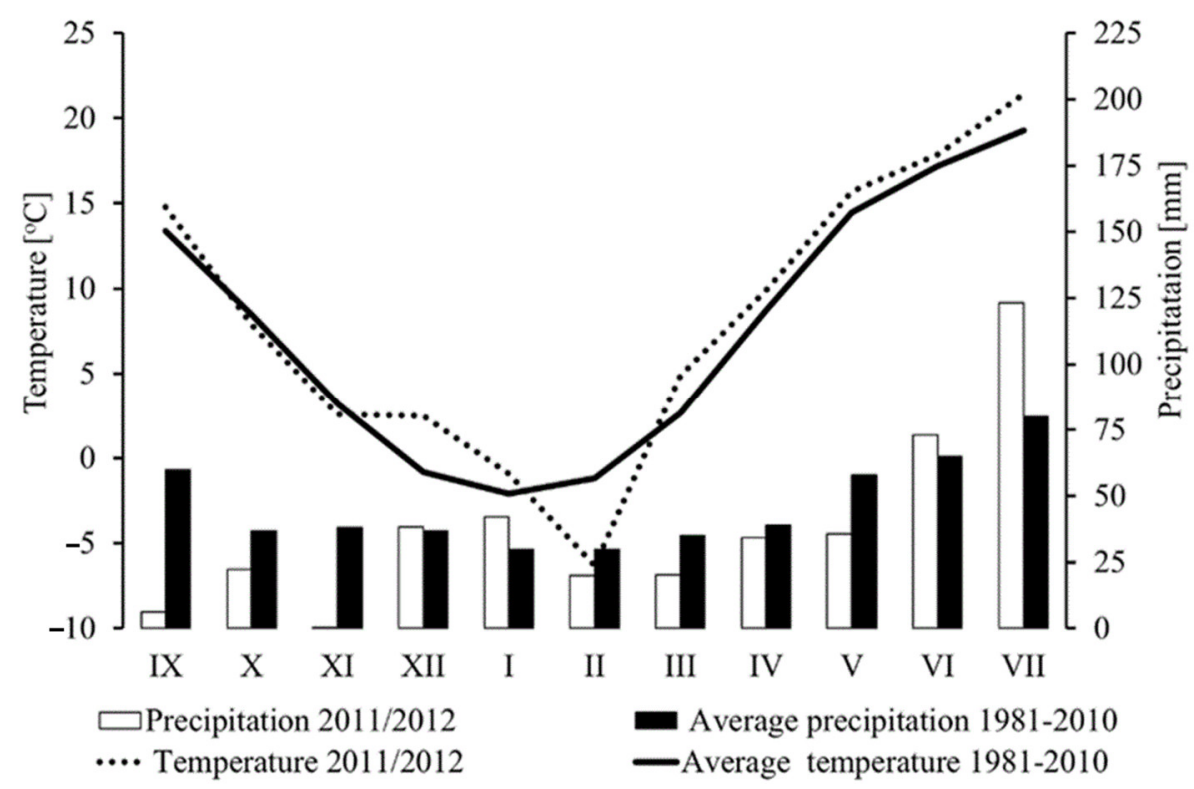

Figure 2. Monthly mean air temperature $\left({ }^{\circ} \mathrm{C}\right)$ and monthly sum of precipitation $(\mathrm{mm})$ in years $2011 / 2012$.

The weather in the 2012/2013 season was characterized by low temperatures in December, January and March (Figure 3). Especially in March the thermal conditions (average temperature $-1.6{ }^{\circ} \mathrm{C}$ ) differed significantly compared to the other years of the study. The average temperature in March was lower by as much as $4.3^{\circ} \mathrm{C}$ lower compared to the long-term mean. Such thermal conditions limited the spring vegetation of plants.

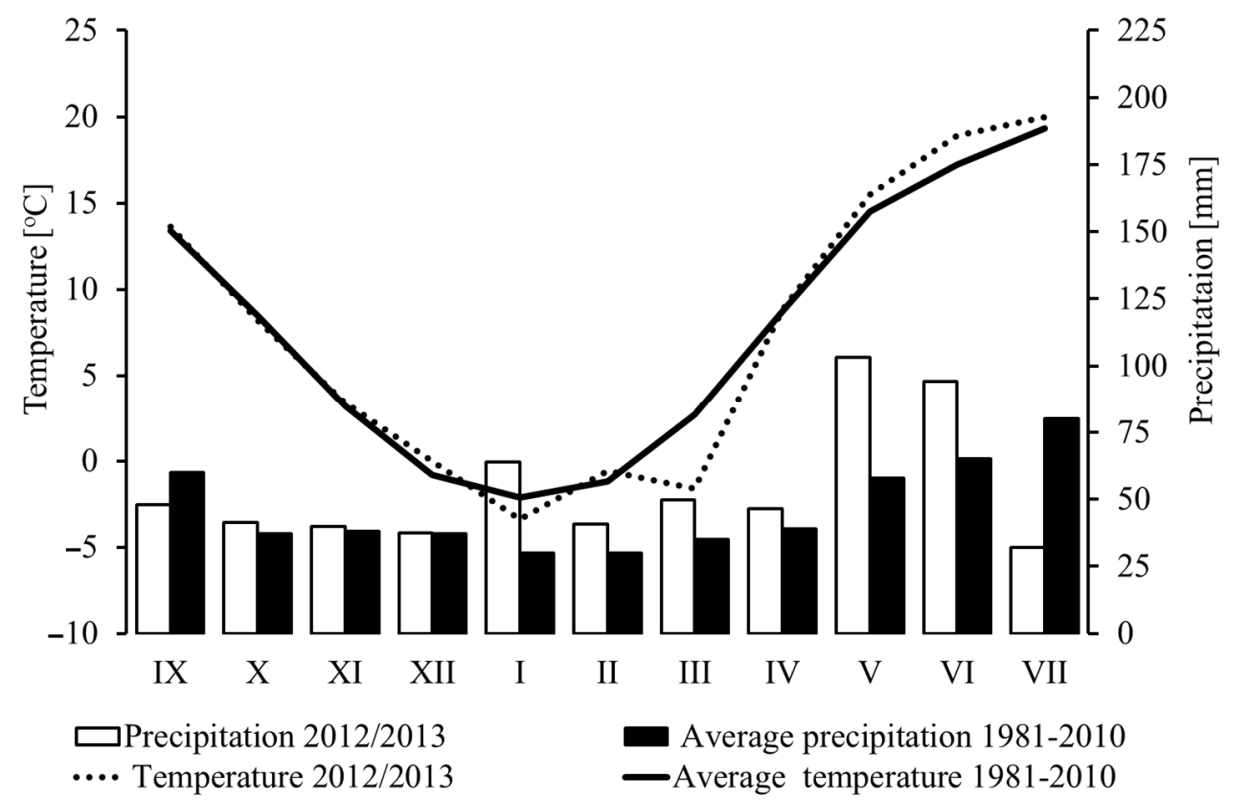

Figure 3. Monthly mean air temperature $\left({ }^{\circ} \mathrm{C}\right)$ and monthly sum of precipitation $(\mathrm{mm})$ in years 2012/2013. 
Humidity conditions during the years of field research were conditioned by the extremely dry autumn in 2012, where from September to November the precipitation was $29 \mathrm{~mm}$, constituting $24 \%$ of the long-term precipitation mean (Figure 3). A small precipitation deficit occurred in the period of rapid wheat growth from March to June in the years 2011 (Figure 1) and 2012 (Figure 3), in which the sum of precipitation was $192 \mathrm{~mm}$ and $131 \mathrm{~mm}$, respectively, which is $41 \mathrm{~mm}$ and $34 \mathrm{~mm}$ lower than the long-term precipitation mean. However, July saw an excessive precipitation. In 2011 and 2012 the monthly precipitation was $223 \mathrm{~mm}$ and $123 \mathrm{~mm}$, respectively (278\% and $154 \%$ of the longterm mean). Humidity conditions in 2013 (Figure 3) were conditioned by high precipitation from March to June, particularly high precipitation occurring in May (103 mm, 178\% of the long-term mean). In July, during the grain filling period, humidity was very low ( $40 \%$ of the long-term mean precipitation).

\subsection{Chemical Analyses}

\subsubsection{Determination of Alkylresorcinol Content}

The analysis was performed by spectrophotometr method [16]. Grains were ground to a particle size $<0.5 \mathrm{~mm}$. Alkylresorcinols were extracted with acetone from the weighed amount of $1 \mathrm{~g}$ within in the time of $3 \mathrm{~h}$ at $55^{\circ} \mathrm{C}$ in a water bath. The content of alkylresorcinols was determined using acetone extracts after developing a color reaction with the two-phase p-nitroaniline and measuring the absorbance of the colored solution at $435 \mathrm{~nm}$. To prepare the calibration curve, the orcinol was used.

\subsubsection{Determination of Soluble Pentosans}

The orcinol-hydrochloric acid method of Albaum and Umbreit [35] was used for pentose determination was used. It consisted of heating in boiling water for $30 \mathrm{~min}$ a solution containing $3 \mathrm{~mL}$ of pentose, $3 \mathrm{~mL}$ of $0.1 \%$ ferric chloride in concentrated hydrochloric acid, and $0.3 \mathrm{~mL}$ of $1.0 \%$ orcinol in $100 \%$ ethanol, cooling, and determining absorbance at $670 \mathrm{~nm}$.

\subsubsection{Determination of the Activity of Tripsin Inhibitors}

Tripsin inhibitors were determined by the method of PN-EN ISO 14902 [36]. Trypsin inhibitors were extracted from the sample at $\mathrm{pH}$ 9.5. The residual trypsin activity was measured by adding benzoyl-L-arginino-p-nitroanilide (L-BABA) as substrate. The amount of p-nitroanilide released was measured spectrometrically.

\subsection{Statistical Analysis}

Results recorded in the course of conducted chemical analyses were subjected to statistical analysis with the use of STATISTICA ver. 13.1 (StatSoft, Inc., Tulsa, OK, USA) and Microsoft ${ }^{\circledR}$ Excel 2020, Microsoft 365 (Addinsoft, Inc., Brooklyn, NY, USA) software packages. In order to compare the content of individual chemical compounds between the years of experiments Tukey's multiple comparison procedure was used, with identical letters denoting a lack of differences at the significance level of 0.05 . Moreover, a step linear discriminatory analysis (SLDA), cluster analysis by Ward method and the principal component analysis (PCA) were used in order to separate groups of analyzed populations.

\section{Results and Discussion}

It was found that the content of the anti-dietary substances in rye grains was significantly influenced by genetic factors and weather conditions during the period of field cultivation, i.e., in the years 2010-2013, and in the case of alkylresorcinols and water-soluble pentosans, the production technology was also used (Table 2). 
Table 2. The content of selected anti-nutritive substances in the grains of winter rye varieties depend on growing season variety, and production technology.

\begin{tabular}{|c|c|c|c|}
\hline Specification & $\begin{array}{l}\text { Alkylresorcinols Content } \\
\qquad\left(\mathrm{mg} \cdot \mathrm{kg}^{-1}\right)\end{array}$ & $\begin{array}{c}\text { Water Soluble Pentosans } \\
\text { Content } \\
\text { (\% d.m.) }\end{array}$ & $\begin{array}{l}\text { Activity of Tripsin } \\
\text { Inhibitors }\left(\mathrm{mg} \cdot \mathrm{g}^{-1}\right)\end{array}$ \\
\hline \multicolumn{4}{|c|}{ Growing season } \\
\hline $2010 / 2011$ & $578 \pm 52^{b}$ & $1.89 \pm 0.14^{b}$ & $4.60 \pm 0.74^{c}$ \\
\hline $2011 / 2012$ & $485 \pm 48^{\mathrm{a}}$ & $1.30 \pm 0.22^{\mathrm{a}}$ & $0.60 \pm 0.10^{\mathrm{a}}$ \\
\hline $2012 / 2013$ & $579 \pm 30^{b}$ & $1.88 \pm 0.15^{b}$ & $2.24 \pm 0.18^{b}$ \\
\hline \multicolumn{4}{|c|}{ Variety (A) } \\
\hline Brasetto & $535 \pm 59^{a}$ & $1.58 \pm 0.27^{\mathrm{a}}$ & $2.55 \pm 0.23^{b}$ \\
\hline Visello & $563 \pm 69^{b}$ & $1.73 \pm 0.58^{b}$ & $2.80 \pm 0.22^{b}$ \\
\hline Dańkowskie Diament & $543 \pm 57^{a b}$ & $1.72 \pm 0.29^{b}$ & $2.01 \pm 0.16^{\mathrm{a}}$ \\
\hline Kier & $550 \pm 30 \mathrm{ab}$ & $1.72 \pm 0.40^{\mathrm{b}}$ & $2.56 \pm 0.23^{b}$ \\
\hline \multicolumn{4}{|c|}{ Production technology (B) } \\
\hline Integrated & $544 \pm 60^{\mathrm{a}}$ & $1.58 \pm 0.12^{\mathrm{a}}$ & $2.52 \pm 0.18^{\mathrm{a}}$ \\
\hline Intensive & $584 \pm 49^{b}$ & $1.73 \pm 0.16^{b}$ & $2.44 \pm 0.19^{\mathrm{a}}$ \\
\hline
\end{tabular}

$\mathrm{a}, \mathrm{b}, \mathrm{c}$-The same letters indicate no significant differences at significance level $\alpha=0.05$.

Due to the demonstrated significant differences in the content of anti-dietary substances in rye grains from individual years of harvest, the weather conditions in individual growing seasons were analyzed (Figures 1-3). Rye grains harvested in 2012 were found to have the lowest content of these compounds (Table 2, Figure 4). The exception was the population variety Kier whose grains did not show statistically significant differences in alkylresorcinol content throughout the years (Figure 4A). The average alkylresorcinol content in rye grains harvested in 2012 was $485 \mathrm{mg} \cdot \mathrm{kg}^{-1}$, soluble pentosans $1.30 \% \mathrm{~d}$.m., while the activity of trypsin inhibitors was at a level of $0.60 \mathrm{mg} \cdot \mathrm{g}^{-1}$ (Table 2). A higher synthesis of anti-nutritional compounds was found in the 2010/2011 and 2012/2013 growing seasons. The average alkylresorcinol contents of rye grains from these seasons were $578 \mathrm{mg} \cdot \mathrm{kg}^{-1}$ and $579 \mathrm{mg} \cdot \mathrm{kg}^{-1}$, while soluble pentosans were $1.89 \% \mathrm{~d} . \mathrm{m}$. and $1.88 \% \mathrm{~d} . \mathrm{m}$., respectively. However, a considerably higher activity of trypsin inhibitors $\left(4.60 \mathrm{mg} \cdot \mathrm{g}^{-1}\right)$ was found in rye grains harvested in 2011. An increased synthesis of anti-nutritional substances in rye grains was associated with stress conditions during the growing season of the plants. In the 2010/2011 growing season the stress was caused by large deficiencies in precipitation during the period of intensive plant growth in the stem formation stage. There were also frosts in May 2011, which according to Doroszewski et al. [37] may have been an additional stress factor for plants. During the growing season 2012/2013, the stress conditions for the development of winter rye were associated with large temperature drops in March, which caused a delay in vegetation of the plants. The plants starting their vegetation were weakened and more exposed to stress conditions. In addition, in the same year, the rainfall in May and June was above the long-term rainfall mean, which caused a large plant infection by fungal diseases. The plants, defending themselves against pathogens, synthesize larger amounts of bioactive substances [38]. The relationship of weather conditions with the accumulation of anti-nutritive compounds in cereal grains is indicated by the results of many studies [11,23,38-41]. Jaśkiewicz and Szczepanek [41] showed higher accumulation of alkylresorcinols in triticale grains in the years with a cold April and warm May. On the other hand, low accumulation of these compounds was caused by limited precipitation in the stages of tillering and stem formation (March, April) and excess precipitation during grain ripening. Bellato et al. [39] demonstrated that weather conditions during the growing season have a decisive influence on the accumulation of alkylresorcinols in durum wheat grains. A higher content of alkylresorcinolols was found in wheat grains from the location with the lowest amount of precipitation. Buksa et al. [3] also showed that the lower amount of precipitation during the growing season caused a higher concentration of pentosans in rye grains, including the fraction that was insoluble in water. According to the above-mentioned authors and Boskov Hansen et al. [42], the weather conditions in a 
given cultivation year, have a much greater effect on the pentosan content in rye grains than the genotype.
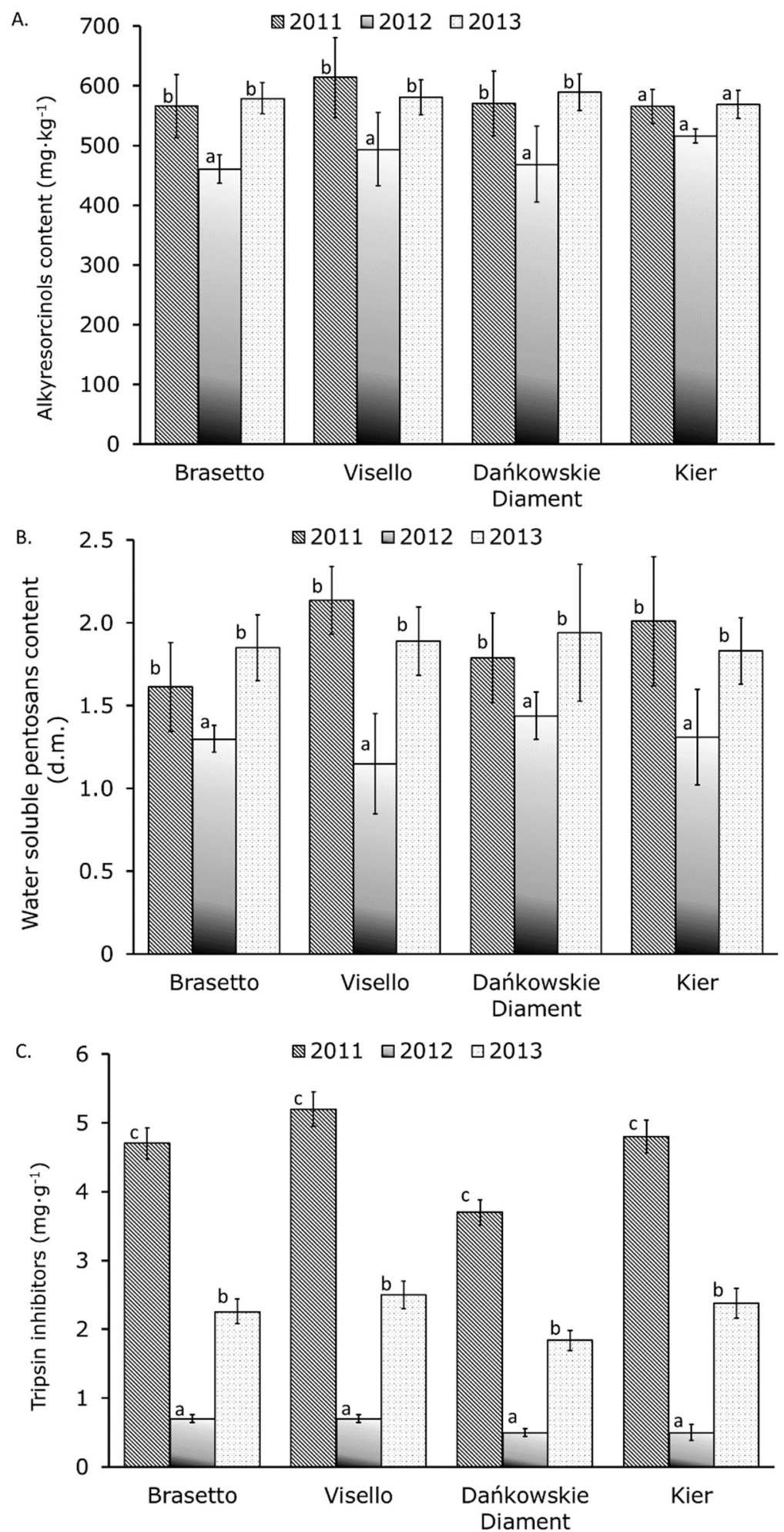

Figure 4. Content of selected anti-nutritive components-alkylresorcinols (A), water-soluble pentosans (B) and trypsin inhibitors (C) in grains of 4 rye varieties in 2011-2013. ${ }^{a, b, c}-$ The same letters indicate no significant differences at significance level $\alpha=0.05$. 
The analysis of variance showed that winter rye varieties had a varied content of anti-nutritive compounds in their grains (Table 2). During the three-year study period, most alkylresorcinols were found in the grains of the hybrid variety Visello (on average $563 \mathrm{mg} \cdot \mathrm{kg}^{-1}$ ). The lowest content of alkylresorcinols in the grains was recorded in the hybrid variety Brasetto (on average $535 \mathrm{mg} \cdot \mathrm{kg}^{-1}$ ). The content of alkylresorcinols did not differentiate between the grains of population rye varieties: (Dańkowskie Diament and Kier). Studies by many authors $[13,41]$ indicate that the level of alkylresorcinols in rye grains depends on a genetic factor. Makarska et al. [15] obtained alkylresorcinol content in rye grains in the range from $581 \mathrm{mg} \cdot \mathrm{kg}^{-1}$ to $707 \mathrm{mg} \cdot \mathrm{kg}^{-1}$. In the study by Kulawianek et al. [43], the average alkylresorcinol content in rye grains was $1100 \mathrm{mg} \cdot \mathrm{kg}^{-1} \mathrm{~d} . \mathrm{m}$., whereas the most of these compounds were accumulated in the grains of the hybrid variety Gradan (1152 mg. $\mathrm{kg}^{-1} \mathrm{~d} . \mathrm{m}$.), and the least in the grains of the population variety Amilo (1058 $\mathrm{mg} \cdot \mathrm{kg}^{-1} \mathrm{~d}$.m.). In our study, the use of discriminatory stepby-step analysis (SLDA) showed that based on the alkylresorcinol content, the studied population can be divided into 3 aggregations, of which not all treatments were matched to the separated subgroups (Figure 5A). Therefore, it should be concluded that on the basis of the alkylresorcinol content it is not possible to fully separate the tested varieties, which indicates the weak discrimination power of this variable.

(A)

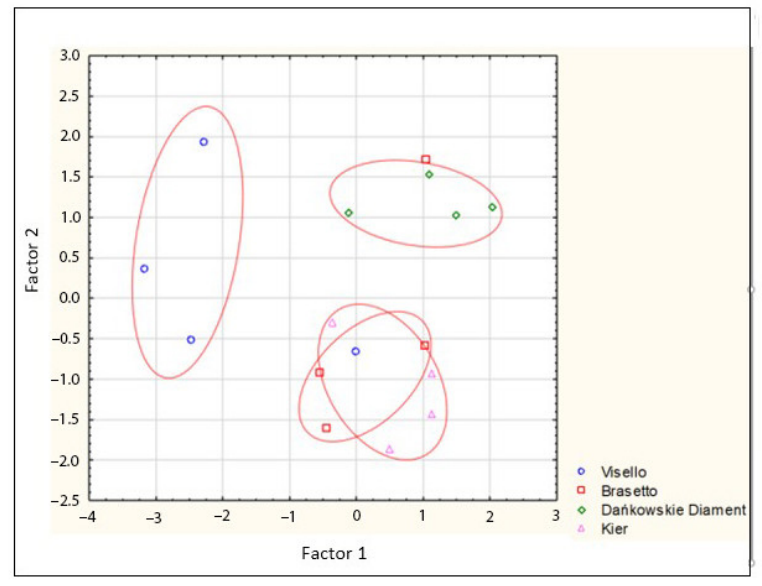

(B)

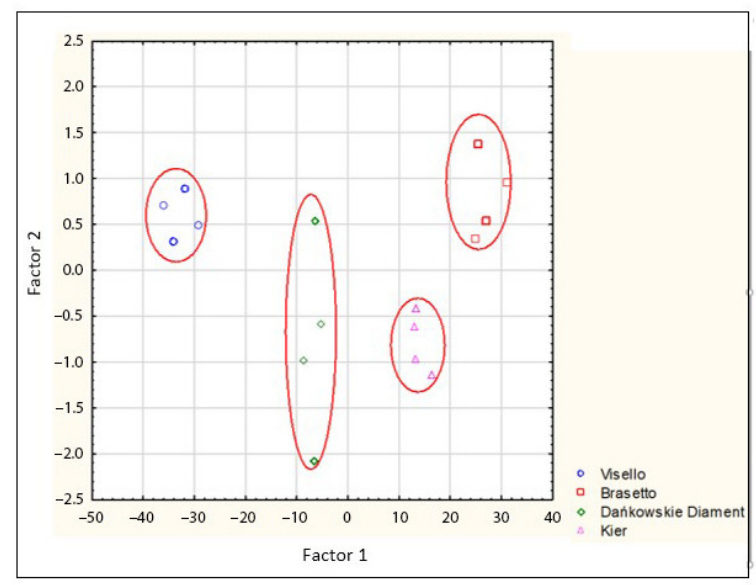

Figure 5. Cont. 
(C)

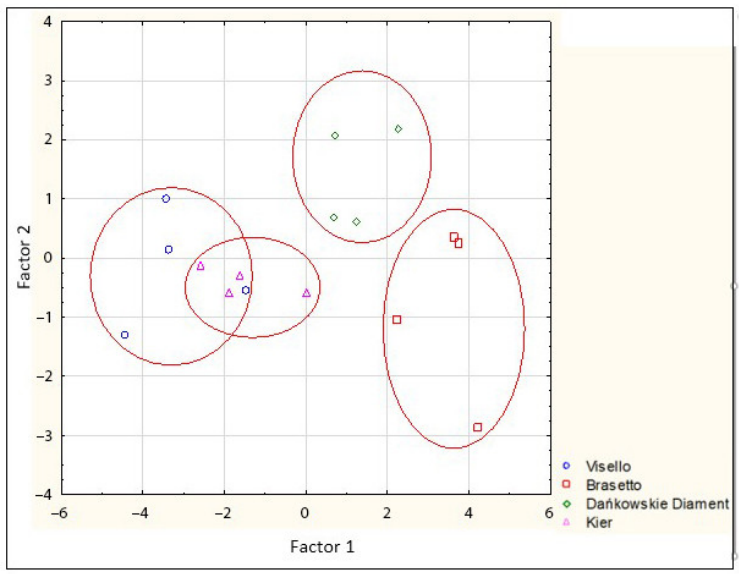

Figure 5. SLDA analysis for alkylresorcinol (A), water-soluble pentosans (B) and trypsin inhibitors (C) in rye grains in 2011-2013.

Our research showed that the content of water-soluble pentosans in rye grains depended on a genetic factor. The grains of the hybrid variety Brasetto showed the lowest content of water-soluble pentosans (on average $1.58 \% \mathrm{~d} . \mathrm{m}$.), whereas in the grains of the other varieties, the content of this component was at the level of $1.72-1.73 \%$ d.m. (Table 2). Buksa et al. [44] demonstrated that rye varieties exhibit high variability in the content of these compounds in the grains, while Kucerova [45] found no significant differences in the content of pentosans in rye varieties. In our own study, a discriminatory step-by-step analysis (SLDA) for the content of water-soluble pentosans showed a satisfactory distribution on the plane of the variables with full separation into groups (Figure 5B). This means that the content of these compounds is a characteristic trait of the tested varieties, and at the same time, has a high discriminating power.

According to Schwarz et al. [11] and Kulichova et al. [13], compared to other plants, rye shows a four-fold higher activity regarding inhibiting trypsin. Our research showed that, similarly to the work of Kulichova et al. [13], the activity of trypsin inhibitors was significantly dependent on the genetic factor. The highest activity of trypsin inhibitors (average $2.80 \mathrm{mg} \cdot \mathrm{g}^{-1}$ ) was found in the rye grain of the Visello hybrid cultivar (Table 2). In the grain of the second hybrid cultivar-Brasetto and the population cultivar Kier, the activity of trypsin inhibitors was at a similar level (average: 2.55 and $2.56 \mathrm{mg} \cdot \mathrm{g}^{-1}$, respectively). The grain of the population cultivar Dańkowskie Diament was characterized by the lowest trypsin activity (average $2.01 \mathrm{mg} \cdot \mathrm{g}^{-1}$ ). In the rye grain studied by Schwarz et al. [11] the activity of trypsin inhibitors was slightly lower $\left(1.6 \mathrm{mg} \cdot \mathrm{g}^{-1}\right)$.

The application of the discriminatory step-by-step analysis (SLDA) showed that, similarly to alkylresorcinols, the studied population was divided into 3 clusters (Figure 5C), of which not all the treatments were matched to the separated subgroups, and hence, it is not possible to fully separate the studied varieties, which indicates the weak discrimination power of this variable.

Due to the fact that the varieties belonged to two utility groups of rye (hybrid and population), grouping using the Ward method was performed in order to determine the clusters and agglomeration possibilities of individual varieties (Figure 6). On the basis of the analysis of clusters, it was found that taking into account the content of water-soluble pentosans and trypsin inhibitors, the varieties formed two agglomerates based on the determined compounds. The diagram of the tree in Figure $6 \mathrm{~B}$ created on the basis of the content of water-soluble pentosans allowed us to separate two clusters, namely hybrid and population rye, which indicates the relationship between the form of rye and the content of soluble pentosans. A similar pattern was found for the alkylresorcinol content, but here the division was not significant and only the Visello and Brasetto varieties (hybrid rye) could 
be separated. In the analyzed years the arrangement of individual varieties in groups, and at the same time their Euclidean distances, were different.

(A)

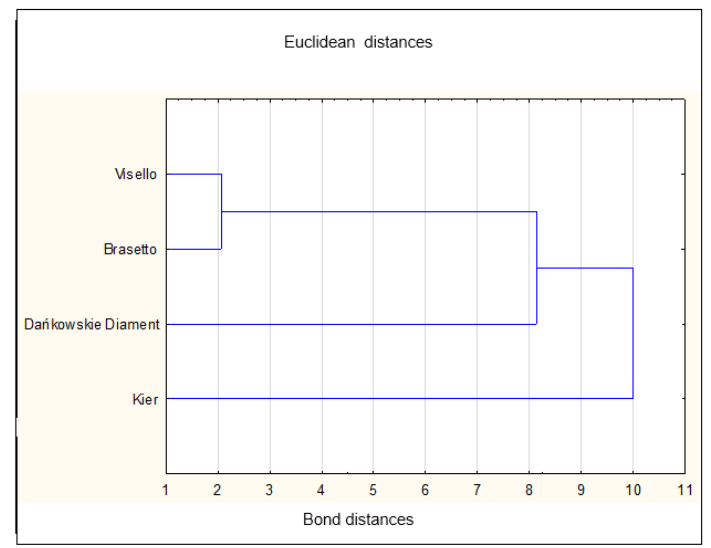

(B)

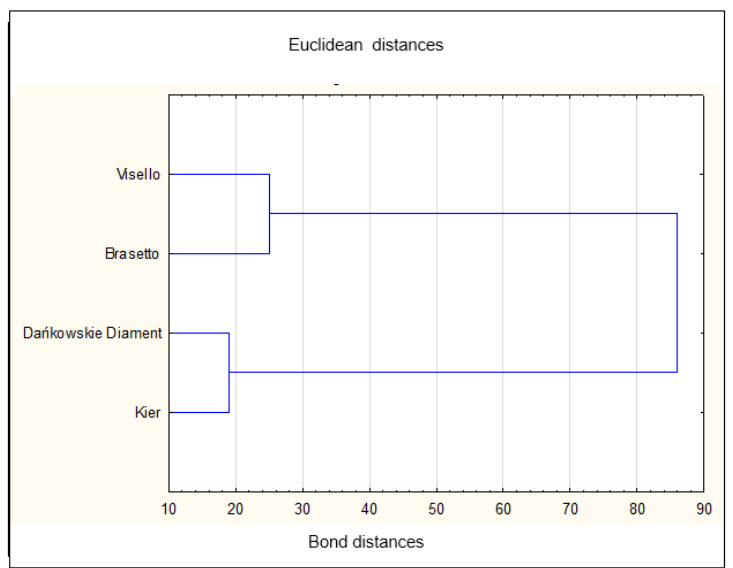

(C)

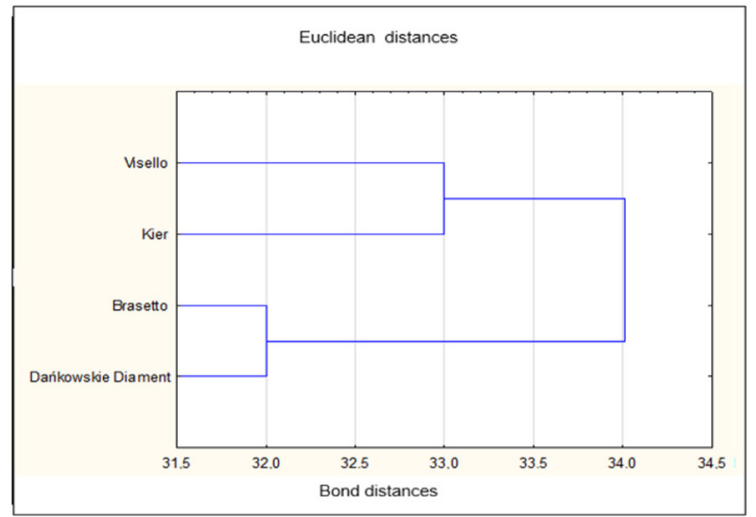

Figure 6. Grouping by Ward method for the content of alkylresorcinols (A), water-soluble pentosans (B) and trypsin inhibitors (C) in rye grains in the years 2011-2013.

So far, little research has been undertaken in the literature on the influence of production technology on the quantitative profile of anti-nutritional compounds in rye grain. Our own research shows that the production technology had a significant impact on the content of alkylresorcinols and water-soluble pentosans in rye grains, but did not differentiate between the concentration of trypsin inhibitors (Table 2, Figure 7). The analysis of the main components showed that the case spread on the predicator plane is clearly divided into 2 groups depending on the production technology (Figure 7A), which additionally 
emphasizes the distribution of variables (Figure 7B) indicating a significant effect of the production technology and its relation to the content of water-soluble pentosans and alkylresorcinols. During the three-year research period winter rye cultivated with the use of intensive production technology contained on average $7 \%$ more alkylresorcinols and $9 \%$ more water-soluble pentosans compared to the grains from integrated cultivation. Ross et al. [46] indicate that the level of alkylresorcinols in the grains, next to the variety, is significantly influenced by such factors as fertilization or pesticide use. The studies by Jaśkiewicz and Szczepanek [41] show that the intensive production technology promotes higher accumulation of alkylresorcinols in the grains of winter triticale as compared to integrated technology. A similar opinion is also held by Czaban et al. [47], who demonstrated a higher concentration of bioactive components in the grains of wheat grown in intensive technology compared to the grains from the integrated and economical technologies.

(A)

Projection of variables at the plane $(1 \times 2)$ Active and additional* variables

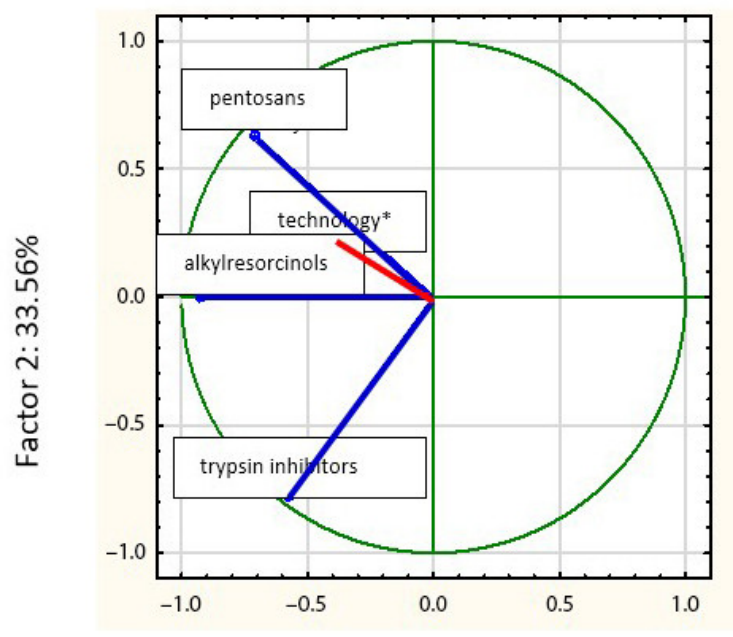

Factor 1: 55.69\%

(B)

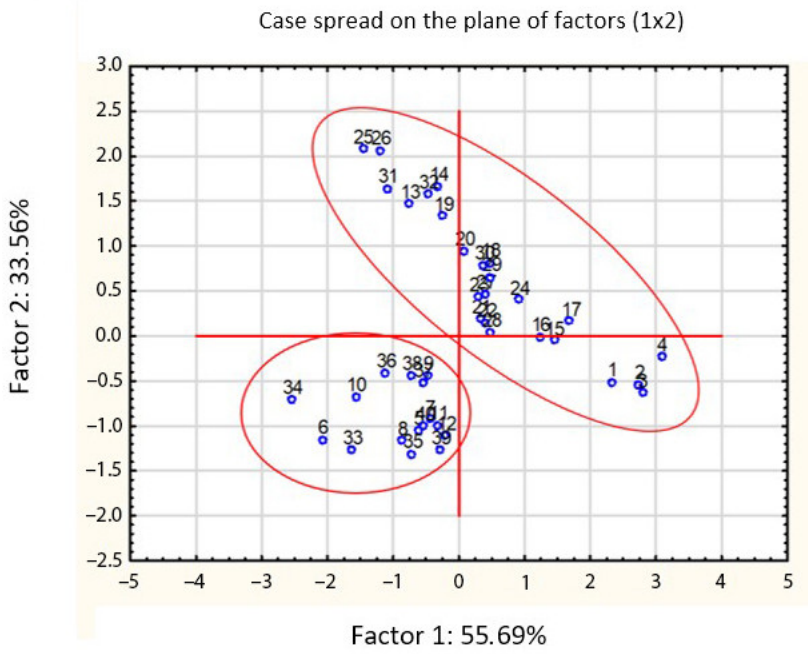

Figure 7. Results of the analysis of main components: projection of variables at the plane (A) and case spread on the plane of factors (B) for the production technology based on the content of alkylresorcinols, pentosans and trypsin inhibitors in rye grains in 2011-2013. 


\section{Conclusions}

The conducted research has shown that the content of anti-nutritional substances in rye grain (alkylresorcinols, water-soluble pentosans and the activity of trypsin inhibitors) is genetically determined. The relationship between the utility form of rye (population, hybrid) and the content of water-soluble pentosans was found. It was shown that the application of intensive production technology in the cultivation of rye increased the content of alkylresorcinols and water-soluble pentosans in rye grain, while the activity of trypsin inhibitors in rye from intensive and integrated production technology was at a similar level.

Author Contributions: Conceptualization, J.G., methodology, M.W.; A.S., statistical analysis, K.S.-S. and A.S., weather conditions analysis, A.N., Writing-original draft, A.S., G.C.-P., J.G. and D.D., Writing - review and editing, A.S., G.C.-P., J.G. and D.D. All authors have read and agreed to the published version of the manuscript.

Funding: This research was supported by Polish Ministry of Agriculture and Rural Development as part of task 3.4 of the Long-Term Program realized by Institute of Soil Science and Plant Cultivation in Pulawy.

Data Availability Statement: The data presented in this study are available on request from the corresponding author.

Conflicts of Interest: The authors declare no conflict of interest.

\section{References}

1. Poutanen, K.; Katina, K.; Heiniö, R. Rye. In Bakery Products Science and Technology; Simpson, B.K., Ed.; John Wiley \& Sons, Ltd.: Hoboken, NJ, USA, 2014; pp. 75-87.

2. FAOSTAT. FAO Statistic Division 2020. Available online: http:/ / faostat.fao.org (accessed on 5 October 2020).

3. Buksa, K.; Nowotna, A.; Gambuś, H.; Krawontka, J.; Sabat, R.; Noga, M. Technological evaluation and chemical composition of rye grain of selected varieties cultivated by 3 consecutive years. Acta Agroph. 2012, 19, 265-276.

4. Święcicki, W.K.; Surma, M.; Koziara, W.; Skrzypczak, G.; Szukała, J.; Bartkowiak-Broda, I.; Zimny, J.; Banaszak, Z.; Marcinak, K. Modern technologies in crop production friendly for man and environment. Pol. J. Agron. 2011, 7, 102-112.

5. Cacak-Pietrzak, G. The use of rye for consumption and other purposes. In Quality Control in the Circulation and Processing of Cereal Grains; IBPRS: Warsaw, Poland, 2016; pp. 18-19.

6. Horoszkiewicz-Janka, J.; Mrówczyński, M. Methodology of Integrated Rye Protection and Production-For Adviser; Institute of Plant Protection-National Research Institute: Poznań, Poland, 2016; p. 138.

7. Jasińska, I.; Kołodziejczyk, P.; Michniewicz, J. Rye seed as a potential source of pro-health compounds in diet. Żywność. Nauka. Technologia. Jakość 2006, 2, 85-92.

8. Stępniewska, S.; Słowik, E.; Cacak-Pietrzak, G.; Romankiewicz, D.; Szafrańska, A.; Dziki, D. Prediction of rye flour baking quality based on parameters of swelling curve. Eur. Food Res. Technol. 2018, 244, 989-997. [CrossRef]

9. Stẹpniewska, S.; Hassoon, W.H.; Szafrańska, A.; Cacak-Pietrzak, G.; Dziki, D. Procedures for Breadmaking Quality Assessment of Rye Wholemeal Flour. Foods 2019, 8, 331. [CrossRef]

10. European Flour Millers. The European Flour Milling Industry; European Flour Milling Association: Bruksela, Belgium, 2020; pp. 98-102.

11. Schwarz, T.; Kuleta, W.; Turek, A.; Tuz, R.; Nowicki, J.; Rudzki, B.; Bartlewski, M. Assessing the efficiency of using a modern hybrid rye variety for pig fattening, with emphasis on production costs and carcass quality. Anim. Prod. Sci. 2014, 55, 467-473. [CrossRef]

12. Winiarska-Mieczan, A. Bowman-Birk trypsin inhibitors: Their structure and value in human and animal feeding. Medycyna Weterynaryjna 2007, 63, 276-281.

13. Kulichová, K.; Sokol, J.; Nemeček, P.; Maliarová, M.; Maliar, T.; Havrlentová, M.; Kraic, J. Phenolic compounds and biological activities of rye (Secale cereale L.) grains. Open Chem. 2019, 17, 988-999. [CrossRef]

14. Ross, A.B.; Kamal-Edin, A.; Aman, P. Dietary alkylresorcinols: Absorption, bioactivities and possible use as biomarkers of whole grain wheat- and rye-rich foods. Nutr. Rev. 2004, 62, 81-95. [CrossRef]

15. Makarska, E.; Gruszecka, D.; Grądzielewska, A. The content of alkylresorcinols and trypsin inhibitors activity in translocational rye strains and parental components Secale cereale L. and Dasypyrum villosum (L.). Ann. Univ. Mariae Curie-Skłodowska 2007, LXII, 117-121.

16. Tłuścik, F. Localization of the alkylresorcinols in rye and wheat caryopses. Acta Soc. Bot. Pol. 1978, 47, 211-2018. [CrossRef]

17. Chen, Y.; Ross, A.B.; Aman, P.; Kamal-Eldin, A. Alkyresorcinoles as markers of whole grain wheat and rye in cereal products. J. Agric. Food Chem. 2004, 52, 8242-8246. [CrossRef] [PubMed] 
18. Landberg, R.; Kamal-Eldin, A.; Salmenkalio-Marttila, M.; Rouau, X.; Aman, P. Lokalization of alkylresorcinols in wheat, rye and barley kernels. J. Cereal Sci. 2008, 48, 401-406. [CrossRef]

19. Fardet, A. New hypotheses for the health-protective mechanisms of wholegrain cereals: What is beyond fiber? Nutr. Res. Rev. 2010, 23, 65-134. [CrossRef] [PubMed]

20. Lipiec, A.; Pisarski, K. Anti-nutritional substances in feed. Med. Weter. 1994, 50, 152-155.

21. Stasiuk, M.; Kozubek, A. Biological activity of phenolic lipids. Cell. Mol. Life Sci. 2010, 67, 841-860. [CrossRef] [PubMed]

22. Boros, D. Alkylresorcinols of cereal grains-Their importance in food and feed. Biuletyn IHAR 2015, 277, 7-20.

23. Ziegler, J.U.; Steingass, C.B.; Longing, C.F.H.; Wurschum, T.; Carle, R.; Schweiggert, R.M. Alkylresorcinol Composition Allows The Differentition OF Triticum Spp. Having Different Degrees of Ploidy. J. Cereal Sci. 2015, 65, 244-251. [CrossRef]

24. Fraś, A.; Boros, D. Influence of environmental conditions on the variability of alkylresorcinols content in winter wheat grain. Biuletyn IHAR 2015, 278, 17-25.

25. Jones, H.; Clarke, S.; Haigh, Z.; Pearce, H.; Wolfe, M. The effect of the year of wheat variety release on productivity and stability of performance on two organic and two mon-organic farms. J. Agric. Sci. 2010, 148, 303-317. [CrossRef]

26. Kobylayansky, V.D.; Kuznetsova, L.I.; Solodukhina, O.V.; Lavrentyeva, N.S.; Timina, A. Propects of using Low-Pentosan grain fodder Rye for baking purposes. Russ. Agric. Sci. 2019, 45, 1-4. [CrossRef]

27. Girhammar, U.; Nair, B.M. Isolation, separation and characterization of water soluble non-starch polysaccharides from wheat and rye. Food Hydrocolloid 1992, 6, 285-299. [CrossRef]

28. Boros, D. The viscosity of soluble arabinoxylans is an indicator of the nutritional value of rye. Monogr. Sci. Pap. IHAR 2002, 16, 44 .

29. Lingling, L.; Jianjun, L.; Ming, S.; Liyun, L.; Bihao, C. Study on transforma-tion of cowpea trypsin inhibitor gene into cauliflower (Brassica oleracea L. var. botrytis). Afr. J. Biotechnol. 2005, 4, 45-49.

30. Ng, T.B.; Lam, S.K.; Fong, W.P. A homodimeric sporamin-type trypsin inhibitor with antiproliferative, HIV reverse transcriptaseinhibitory andantifungal activities from wampee (Clausena lansium) seeds. Biol. Chem. 2003, 384, 289-293. [CrossRef]

31. Roy, D.M.; Schneeman, B.O. Effect of soy protein, casein and trypsin inhibi-tor on cholesterol, bile acids and pancreatic enzymes in mice. J. Nutr. 1981, 111, 878-885. [CrossRef]

32. Kulasek, G.; Leontowicz, H.; Krzemiński, R. Bioactive substances in food for humans and animals (part I). Anti-nutritional factors. Mag. Wet. 1995, 15, 39-44.

33. Piasecka-Kwiatkowska, D.; Warchalewski, J.R. The cereal protein inhibitors of hydrolytic enzymes and their role. Part I Protein inhibitors of alpha-amylase. Żywność 2000, 2, 110-119.

34. Piasecka-Kwiatkowska, D.; Warchalewski, J.R. The cereal protein inhibitors of hydrolytic enzymes and their role. Part II Protein inhibitors of proteinases. Żywność 2000, 3, 33-38.

35. Album, H.G.; Umbereit, W.W. Differentiation between ribose-3phosphate and ribose-5 phosphate by means of the orcinol-pentose reaction. J. Biol. Chem. 1947, 167, 369-376.

36. ISO. PN-EN ISO 14902:2001. Animal Feeding Stuffs—Determination of Trypsin Inhibitor Activity of Soya Products; International Organization for Standardization: Geneva, Switzerland, 2001.

37. Doroszewski, A.; Wróblewska, E.; Jóźwicki, T.; Mizak, K. Evaluation of damage to fruit and horticulltural plants caused by frosts in may 2011. Acta Agroph. 2013, 20, 269-281.

38. Stuper-Szablewska, K.; Kurasiak-Popowska, D.; Nawracała, J.; Perkowski, J. Quantitative profile of phenolic acids and antioxidant activity of wheat grain exposed to stress. Eur. Food Res. Technol. 2019, 245, 1595-1603. [CrossRef]

39. Bellato, S.; CIccoritti, R.; Del Frate, V.; Sqrulletta, D.M.; Carbone, K. Influence of genotype and environment on the content of 5-n alkylresorcinols, total phenols and on the antiradical activity of whole durum wheat grains. J. Cereal Sci. 2013, 57, 162-169. [CrossRef]

40. Lu, Y.; Lv, J.; Hao, J.; Niu, Y.; Whent, M.; Costa, J.; Yu, L.L. Genotype, environment, and their interactions on the phytochemical compositions and radical scavenging properties of soft winter wheat bran. LWT 2015, 60, 277-283. [CrossRef]

41. Jaśkiewicz, B.; Szczepanek, M. Crop mangament and variety have influence on alkylresolcinol content in triticale grain. Acta Agric. Scand. 2016, 66, 570-574. [CrossRef]

42. Boskov Hansen, R.; Rasmussen, C.V.; Bach Knudsen, K.R.; Hansen, A. Effect of genotype and harvest year on content and composition of dietary fibre in rye (Secale cereale L.) grain. J. Sci. Food Agric. 2003, 83, 76-85. [CrossRef]

43. Kulawianek, M.; Jaromin, A.; Kozubek, A.; Zarnowski, R. Alkylresorcinols in selected Polish rye and wheat cereals and whole-grain products. J. Agric. Food Chem. 2008, 56, 7236-7242. [CrossRef]

44. Buksa, K.; Nowotna, A.; Praznik, W.; Gambuś, H.; Ziobro, R.; Krawonta, J. The role of pentosans and starch in baking of whole meal rye bread. Food Res. Int. 2010, 43, 2045-2051. [CrossRef]

45. Kucerova, J. Effect of location and year on technological quality and pentosane content in rye. Czech J. Food Sci. 2009, 27, 418-424. [CrossRef]

46. Ross, A.B.; Sheperd, M.J.; Bach Knudsen, K.E.; Glitso, L.V.; Bowey, E.; Philips, J.; Rowland, I.; Guo, Z.X.; Massy, D.J.; Aman, P.; et al. Absorption of dietary alkylresorcinols in ileal—Cannulated pigs and rats. Br. J. Nutr. 2003, 90, 787-794. [CrossRef]

47. Czaban, J.; Sułek, A.; Pecio, Ł.; Żuchowski, J.; Podolska, G. Effect of genotype and crop managment systems on phenolic acid content in winter wheat grain. J. Food Agric. Environ. 2014, 11, 1201-1206. 